\title{
Impact of Agricultural Credit on MV Boro Rice Cultivation in Bangladesh
}

\author{
M. A. KABIR Miah ${ }^{1}$, A. K. M. Ashraful A LAM ${ }^{2}$ AND A. H. M. A. RAhMAN ${ }^{3 *}$ \\ ${ }^{1}$ Agricultural Economics Division, Bangladesh Rice Research Institute, Gazipur, Bangladesh \\ ${ }^{2}$ School of Agriculture and Rural Development, Bangladesh Open University, Gazipur, Bangladesh \\ ${ }^{3}$ CIMMYT-Bangladesh, Bangabandhu Sheikh Muzibur Rahman Agricultural University, \\ Gazipur, Bangladesh
}

Received 19 April 2006; received in revised form 18 June 2006; accepted 22 June 2006

\begin{abstract}
An investigation was conducted at Mithapukur and Razarhat upazila under Rangpur and Kurigram districts, respectively to know the requirements, utilization pattern and repayment system of credit and its effect on modern rice cultivation. A total number of 120 rice growers who obtained credit from Rajshahi Krishi Unnayan Bank (RKUB) and Grameen Bank (GB) were interviewed. Another 60 farmers who did not take credit from other sources were also studied. The findings disclosed that the client farmers of RKUB and GB used about 78 and 72 percent credit, respectively for Boro rice production and the rest was used for consumption purpose. The cost of credit of RKUB and GB was Tk. 463 and Tk. 20, respectively. The RKUB farmers had to pay Tk. 252 as entertainment cost. The $G B$ credit users borne 1.13 times higher production cost compared to RKUB users for Boro rice cultivation. Loan users achieved 1.21 times higher rice yield compared to loan non-users. The analysis of resources use efficiency revealed that both credit users and non-users rice growers had failed to use inputs efficiently, either the production inputs were overused or underused. Unavailability of credit and weekly instalment system of repaying loan were the main constraints faced by 38 percent RKUB and 53 percent GB credit users. Small farmers were found to avoid cumbersome procedure of obtaining loan from the institutional sources and they felt better to borrow loan from NGOs.
\end{abstract}

Key words: RKUB, GB, MV Boro rice, credit and farmers.

\section{INTRODUCTION}

With the breakthrough of green revolution of agriculture by adopting modern technologies during the mid-seventies, the demand for agricultural credit has increased tremendously. The modern agricultural farming technology is highly capital-intensive due to intensive use of modern agricultural inputs such as HYV seeds, synthetic fertilizers, pesticides, modern irrigation facilities and farm implements. Most of the farmers cannot afford such big investment due to scarcity of working capital (Hossain, 1985). However, the agrarian economy of Bangladesh is mostly dominated by the small and marginal farmers. Small marketed surplus of food grains and its seasonality along with the need for funds for both farming and family consumption creates cash

\footnotetext{
* Corresponding author: Scientific Officer, CIMMYT-Bangladesh, BSMRAU, Gazipur, Bangladesh.

(C) 2006, School of Agriculture and Rural Development, Bangladesh Open University. All rights reserved.
} 
deficit leading to demand for credit in the agricultural sector. Moreover, the MV Boro rice cultivation in the new agricultural systems is highly input intensive. Consequently, farmers are unable to accumulate enough capital to buy the costly inputs needed for Boro rice cultivation. Early studies indicated that to sustain and accelerate technological change in agriculture for adopting improved practices, credit is essential (Hossain, 1986). Similarly Jaim and Rahman (1985) observed that although rich and middle class farmers generate sufficient surplus after maintaining a higher standard of living, they too feel need for credit in certain period, particularly in Boro seasons.

Farmers take loan both from informal and formal sources. Due to excessive formalities followed by the nationalized banks, informal compound interest mohazoni system still remains in the rural agriculture. Credit are also available from informal sources against advanced sale of crops at prices much below the level prevailing in the market during the harvesting period. Payments for interest charges on such loans constitute a major drain on the current income of the small farmers, which depress their living standard and make the perpetually indebted (Baduri,1973), and in some cases lead to alienation of land which contributes to growing landlessness (Jabber et al., 1981). The formal or institutional sources of credits are Bangladesh Krishi Bank (BKB), Rajshahi Krishi Unnayan Bank (RKUB) Grameen Bank (GB), different Nationalized Commercial Banks, NGOs etc. Those Banks and NGOs provide loan both in cash and kind for accelerating the rice production. One such Grameen Bank (GB) and Rajshahi Krishi Unnayan Bank (RKUB) provides credit in cash to farmers for sustaining technological change in agriculture by adopting improves management practices.

Recently, the government of Bangladesh has given much emphasis to supply agricultural credit to the farmers for achieving self-sufficiency in food within shortest possible time. For desired level of production, more improved technologies and intensive input use is required. Farmers, particularly in Rangpur and Kurigram area take institutional credit for MV Boro rice cultivation. It is assumed that the credit taken for agricultural purposes, i,e. MV rice cultivation is not solely used for the purposes. On the other hand, there is an unwanted cost for obtaining agricultural credit. Therefore, it is necessary to know how the credit is obtained and used and what the impact of credit in MV Boro cultivation is.

\section{Specific Objectives}

i) To know the utilization pattern of agricultural credit;

ii) To measure the relative profitability of Boro rice cultivation for credit users and non-users in the study area; and

iii) To find out the constraints of getting credit by the farmers.

\section{METHODOLOGY}

The study was conducted in Mithapukur upazilla of Rangpur district and Razarhat upazilla of Kurigram district. These two districts were purposively selected based on the higher percentage area under HYV rice. At first a detail list of borrowers and non-borrowers rice growers were collected from the banks and AEO office of the respective upazillas. Then in every upazillas, 30 borrowers' farmers of Rajshahi Krishi Unnayan Bank (RKUB), 30 borrowers' farmers of Grameen Bank (GB) and 30 non borrowers farmers were selected randomly for final interview i.e. a total of 120 borrowers and 60 non-borrowers farmer were selected from the two upazillas. Data were collected during the Boro season, 2004. Collected data were then summarized, tabulated and analyzed in accordance with the objectives.

To estimate the resources use efficiency for borrowers and non-borrowers, the Cobb-Douglas function model was carried out in the following form.

$\mathrm{Y}=\mathrm{a} \mathrm{X}_{1}^{\mathrm{b} 1} \mathrm{X}_{2}^{\mathrm{b} 2} \mathrm{X}_{3}^{\mathrm{b} 3} \mathrm{X}_{4}^{\mathrm{b} 4} \mathrm{X}_{5}^{\mathrm{b} 5} \mathrm{X}_{6}{ }^{\mathrm{b} 6} \mathrm{e}^{\mathrm{Ui}}$

The function was linear by transforming it into following logarithmic (Double log) form:

$$
\log Y=\log a+b_{1} \log X_{1}+b_{2} \log X_{2}+b_{3} \log X_{3}+b_{4} \log X_{4}+b_{5} \log X_{5}+b_{6} \log X_{6}+U_{i}
$$

Where,

$$
Y=\text { Gross Returns from aromatic and non-aromatic rice cultivation }
$$




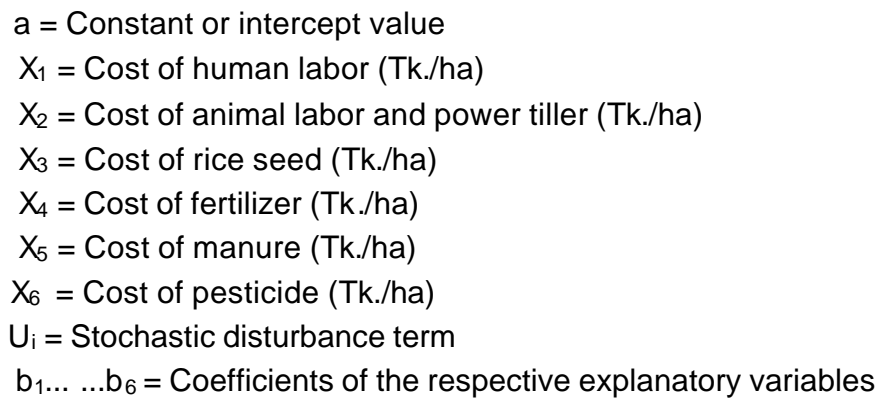

\section{Efficiency analysis}

The resource uses efficiency of the farmers was judged on neo-classical criteria. Neo-classical theory states that, in order to ensure maximum profit and efficiency of resource, resources must be utilized at the level where their marginal value product (MVP) is equal to their marginal factor cost (MFC) under perfect competition. The farmer would select the input level that maximizes the profit (TR-TC). In order to get this marginal value product, the coefficient of production elasticity is multiplied by the output-input ratio of the geometric mean level, which can be shown in the following formula.

MVP $=\frac{\bar{Y}}{\bar{X}_{i}} \times b_{i}$

Where,

$b_{i}=$ regression coefficient of input $X_{i}$

$\bar{X}_{i}=$ mean value (Geometric mean) of $X_{i}$ variable input

$\bar{Y}=$ mean value (Geometric mean) of gross return of $T$. Aman rice.

In order to test this efficiency the ratio of marginal value product (MVP) to the marginal factor cost (MFC) for each input is compared and tested for its equal to 1 (one) i.e. MVP/ MFC $=1$ (Gujarati, 1995).

The resources is considered to be efficiently used as well as profit will be maximized in MV Boro rice production when the ratio of MVP to MFC approaches 1(one) or in other word MVP and MFC for each input are equal.

\section{RESULTS AND DISCUSSION}

\section{Agricultural Credit}

Since more than fifty percent of total labour force employed in the agricultural sector and agriculture is running at the subsistence level, agricultural credit has the outstanding importance in the rural agriculture. Government condoned the interest of agricultural credit up to taka five thousand which was largely contributed to increase agricultural production by relieving burdened agricultural loan of rural farmers. In 1992-93 fiscal year the total disbursement of agricultural credit was 84185 million taka, which increased to 404841 million taka in 2003-04 fiscal year (BBS, 2003). In the current fiscal year 2004-05, the disbursement target of agricultural credit fixed at Tk. 553791 million and up to April 2005 about Tk. 420000 million has disbursed which is about 76 percent of the total target (Table 1) (GOB, 2005).

\section{Cost of Credit}

The cost of credit is one of the important issue of farmers for getting any institutional loan. Table 2 showed that the farmers had to bear some fees for getting loan from RKUB and GB. The total cost of credit of RKUB and GB was Tk. 463 and only Tk. 20, respectively. It indicated that the cost of credit was 23 times higher of RKUB compared to cost of credit of GB. The table revealed that the 
RKUB farmers had to pay Tk. 252 (54\% of total credit cost) as entertainment cost which was fully a matter of undue privilege.

Table 1. Annual target and disbursement of agricultural credit from 1990-91 to 2004-05 financial years

\begin{tabular}{lcc}
\hline Financial year & Disbursement target (Tk. in million) & Actual disbursement (Tk. in million) \\
\hline \hline $1992-93$ & 147441 & 84185 \\
$1993-94$ & 164308 & 110079 \\
$1994-95$ & 216172 & 160544 \\
$1995-96$ & 243427 & 163581 \\
$1996-97$ & 239422 & 167243 \\
$1997-98$ & 252583 & 101453 \\
$1998-99$ & 327001 & 324536 \\
$1999-00$ & 333100 & 285129 \\
$2000-01$ & 326592 & 301967 \\
$2001-02$ & 332664 & 295491 \\
$2002-03$ & 356053 & 327837 \\
$2003-04$ & 437894 & 404848 \\
$2004-05$ & 553791 & 420000 \\
\hline
\end{tabular}

Source: Bangladesh Aurthonoitic Samikha (2005).

Table 2. Cost of getting loan from the RKUB and Grameen Bank

\begin{tabular}{lcccc}
\hline \multirow{2}{*}{ Items } & \multicolumn{2}{c}{ RKUB $^{*}$} & \multicolumn{2}{c}{ GB $^{*}$} \\
\cline { 2 - 5 } & Amount (Tk.) & \% of total & Amount (Tk.) & $\%$ of total \\
\hline \hline Form charge & 29 & 6 & - & - \\
Application fee & 15 & 3 & - & - \\
Transport cost & 30 & 4 & - & - \\
Fooding charge & 26 & 6 & - & - \\
Stamp fee & 16 & 6 & 5 & 25 \\
Deed purpose & 58 & 13 & 10 & 50 \\
Personal cost & 34 & 7 & 5 & 25 \\
Entertainment cost & 252 & 54 & - & - \\
(Undue privilege) & & & & \\
\hline Total & 463 & 100 & & 100 \\
\hline
\end{tabular}

* RKUB : Rajshahi Krishi Uanayan Bank, GB: Grameen Bank

\section{Credit Utilization Pattern}

Different former research showed that the utilization pattern of agricultural credit is one of the important issue for ensuring the productivity of the credit. Table 3 showed that the average farmer received loan Tk. 13840 from RKUB, of which $78.32 \%$ were used for Boro rice production and the rest $21.68 \%$ were used for consumption purpose i.e. used for purchasing food, clothes, medicine etc. On the other hand, farmers who received loan Tk. 7490 from GB used $71.94 \%$ for Boro rice production and $28.06 \%$ were used for consumption purpose. The result showed that the utilization pattern of agricultural credit of RKUB was more productive than that taken from GB because the farmers of RKUB were more resourceful than the farmers of GB. Moreover, the table also showed that the overall utilization pattern of agricultural credit was positive for RKUB and GB farmers in the study area. 
Table 3. Utilization pattern of credit per farm by the sample farmers of Rangpur and Kurigram districts

\begin{tabular}{lcccc}
\hline \multirow{2}{*}{ Activities } & \multicolumn{2}{c}{ RKUB } & \multicolumn{2}{c}{ GB } \\
\cline { 2 - 5 } & Amount (Tk.) & \% of total & Amount (Tk.) & \% of total \\
\hline \hline Purchase of seed /Seedling & 218 & 1.58 & 171 & 2.28 \\
Purchase of fertilizer & 723 & 5.22 & 476 & 6.36 \\
Paying labor & 1620 & 11.71 & 1356 & 18.10 \\
Paying for Animal & 419 & 3.03 & 351 & 4.69 \\
power/Power tiller & 365 & 2.64 & 222 & 2.96 \\
Purchase for manure & 90 & 0.65 & 93 & 1.24 \\
Buying insecticides & 905 & 6.54 & 664 & 8.87 \\
Paying Irrigation charge & 1000 & 7.23 & 1583 & 21.13 \\
Consumption purpose & 2000 & 14.45 & 519 & 6.93 \\
Family expenditure & 6500 & 46.97 & - & - \\
Release land & - & - & 2055 & 27.44 \\
Land Mortgaged in & 13840 & 100.00 & 7490 & 100 \\
\hline Total & & &
\end{tabular}

\section{Profitability}

The total cost of production of Boro rice cultivation of credit users was Tk. 26646 for RKUB farmer and Tk. 28795 for GB farmer in respect of full cost basis. But it was Tk. 24105 for credit non-user sample farmer (Table 4). However, it was Tk. 16099 and Tk. 16119 for RKUB and GB farmers respectively in terns of cash crop basis. And it was Tk. 14070 for credit non-user farmer. The per hectare production of Boro rice was $4580 \mathrm{~kg}$ and $5175 \mathrm{~kg}$ for RKUB and GB farmers respectively. It was $4288 \mathrm{~kg}$ for credit non-user farmer. Per hectare net return was Tk. 8924 and Tk. 14002 for credit user of RKUB and GB farmer respectively in terms of full cost basis. But it was Tk. 8076 for credit non-user farmer. The cash cost basis per hectare net return was Tk. 19473 and Tk. 26678 for RKUB and GB farmer respectively. It was Tk. 18111 for credit non-user farmers. Data showed that the production cost of Boro rice cultivation was higher for GB farmers than RUKB farmer and credit non-user. The data also showed that per hectare net return was higher for GB farmer than RKUB farmer and credit non-user farmer. This was happened due to the fact that the GB farmers were marginal farmer, who could intensively and properly use the input of production during cultivation. Besides, the RUKB farmers were medium farmers who were less efficient in using inputs (Table 4 and Table 5).

Table 4. Cost and return (Tk./ha) of MV Boro rice cultivation by credit user and credit nonusers in Rangpur and Kurigram districts

\begin{tabular}{lrrr}
\hline \multirow{2}{*}{ Item } & \multicolumn{2}{c}{ Credit user } & Non-credit user \\
\cline { 2 - 3 } & \multicolumn{1}{c}{ RKUB } & GB & No25 (63) \\
\hline \hline Human labor & $8934(55)$ & $9762(61)$ & 3810 \\
Family & 3493 & 5796 & 2928 \\
Hired & 5441 & 3966 & 1680 \\
Animal power/power tiller & 2043 & 2178 & 605 \\
Seeds & 713 & 656 & $2340(17)$ \\
Fertilizer & $3011(19)$ & $3084(19)$ & 916 \\
Manure & 1982 & 1540 & 457 \\
Insecticides & 502 & 480 & 4278 \\
Irrigation cost & 4306 & 4051 & 352 \\
Interest on cash Investment @ 10\% & 402 & 403 & 4655 \\
Land rent & 4755 & 4812 & \\
Total cost of production: & & & 14070 \\
\multicolumn{1}{r}{ Cash cost basis } & 16099 & 16119 & 24105 \\
\multicolumn{1}{c}{ Full cost basis } & 26646 & 28795 & \\
\hline
\end{tabular}




\begin{tabular}{lrrc}
\hline \multirow{2}{*}{ Item } & \multicolumn{2}{c}{ Credit user } & \multirow{2}{*}{ Non-credit user } \\
\cline { 2 - 3 } & RKUB & GB & 5.62 \\
\hline Unit cost of production (Tk./kg) & 5.82 & 5.56 & 4288 \\
Paddy yield (Kg/ha) & 4580 & 5175 & 7.50 \\
Paddy price (Tk./kg) & 7.12 & 8.27 & 1782 \\
Straw price (Tk./ha) & 1720 & 2349 & 32181 \\
Gross return (Tk./ha) & 35572 & 42797 & \\
Net return: & & & 18111 \\
$\quad$ Cash cost basis & 19473 & 26678 & 8076 \\
$\quad$ Full cost basis & 8924 & 14002 & \\
Benefit cost ratio: & & & 2.29 \\
$\quad$ Cash cost basis & 2.21 & 2.66 & 1.34 \\
$\quad$ Full cost basis & 1.33 & 1.54 & \\
\hline
\end{tabular}

Table 5. Input used per hectare for MV Boro rice cultivation by the credit user versus credit non-user

\begin{tabular}{lrrr}
\hline \multirow{2}{*}{ Items } & \multicolumn{2}{c}{ Credit user } & \multirow{2}{*}{ Non credit user } \\
\cline { 2 - 3 } & RKUB & GB & 176 \\
Human labor (man day/ha): & 179 & 192 & 76 \\
$\quad$ Family & 70 & 114 & 100 \\
$\quad$ Hired & 109 & 78 & 1680 \\
Animal power /Power tiller (Tk./ha) & 2043 & 2178 & 50 \\
Seed (Kg/ha) & 51 & 47 & 71 \\
Manure (mds/ha) & 107 & 84 & 152 \\
Fertilizer (Kg/ha): & & & 72 \\
$\quad$ Urea & 180 & 178 & 32 \\
TSP & 96 & 96 & 42 \\
MP & 88 & 62 & \\
Gypsum & 64 & 102 & \\
\hline
\end{tabular}

\section{Efficiency measurement}

The Cobb-Douglas production functions were fitted for all borrowers and non-borrowers farmers of the selected areas and are presented in Table 6 . The co-efficient of determinations $\left(R^{2}\right)$ for $G B$ and RKUB farmers were 0.90 and 0.79 , respectively whereas this co-efficient was 0.69 for nonborrowers farmers, which means that the explanatory variables included in each of the model explained $90 \%$ and $79 \%$ of the variation in the borrowers of GB and RKUB, respectively while the variation was $69 \%$ for non-borrower farmers. In all cases $R^{2}$ value was significant at $1 \%$ level. The co-efficient of human labour cost for non-borrowers and GB's borrower were 0.66 and 0.35 , respectively which were significant at $1 \%$ level but this was insignificant for RKUB's borrower in case of MV rice cultivation. This result revealed that an increase in labour cost by $1 \%$ keeping other factors constant would increase the return from MV rice cultivation by about $0.66 \%$ and $0.35 \%$ for non-borrowers and GB's borrowers, respectively. The regression co-efficient of fertilizer used by non-borrowers and GB's borrowers were 0.16 and 0.26 , respectively which was positive and highly significant (at $1 \%$ level) but it was insignificant in case of RKUB borrowers. This also indicated that $1 \%$ increase in fertilizer cost, keeping other factors constant at their geometric mean level would increase the gross return by $0.16 \%$ for non-borrowers and $0.26 \%$ for GB's borrower rice growers. Similarly the co-efficients of seed or seedling cost were significant in the case of non-borrower and GB's borrower though it was negative for non-borrower rice growers but it was insignificant for RKUB's borrowers. The regression co-efficient of pesticide use by RKUB's borrowers $(0.27)$ were significant at $1 \%$ level but it was insignificant in both GB's borrower as well as non-borrower rice growers. Moreover, the co-efficient of tillage cost was insignificant in the case of all borrowers (GB \&RKUB) but it was significant for non-credit users. In the case of human labour use, the cost was highly significant for GB borrowers and non-borrowers farmer (at $1 \%$ level of significance) whereas it was insignificant for RKUB borrowers. 
Table 6. Estimated value of co-efficient and related statistics of Cobb-Douglas production model for non-borrowers versus GB and RKUB credit borrowers of MV rice cultivation

\begin{tabular}{lrrr}
\hline Explanatory variables & Non-credit users & GB credit borrowers & RKUB credit borrowers \\
\hline \hline Intercept & $-3.131(1.032)$ & $0.691(0.632)$ & $2.787(2.116)$ \\
Seed/seedling cost $\left(\mathrm{X}_{1}\right)$ & $-0.256^{*}(2.848)$ & $0.594^{\star *}(5.490)$ & $0.175(1.665)$ \\
Fertilizer cost $\left(\mathrm{X}_{2}\right)$ & $0.155^{\star}(2.120)$ & $0.257^{\star}(3.03)$ & $0.122(1.654)$ \\
Manure cost $\left(\mathrm{X}_{3}\right)$ & $0.176(1.127)$ & $0.045(1.270)$ & $0.113(0.881)$ \\
Pesticide cost $\left(\mathrm{X}_{4}\right)$ & $0.083(0.684)$ & $0.0167(0.314)$ & $0.268^{*}(2.481)$ \\
Irrigation cost $\left(\mathrm{X}_{5}\right)$ & $0.0087(0.034)$ & $-0.0160(0.314)$ & $0.098(0.652)$ \\
Animal power/power tiller & $0.788^{* *}(3.545)$ & $0.0412(0.550)$ & $-0.0107(0.092)$ \\
cost $\left(\mathrm{X}_{6}\right)$ & $0.663^{*}(2.737)$ & $0.353^{* *}(3.007)$ & $0.267(1.534)$ \\
Human labour cost $\left(\mathrm{X}_{7}\right)$ & 0.691 & 0.898 & 0.787 \\
R-square & 5.435 & 29.842 & 14.268 \\
F-values & & &
\end{tabular}

Note: Figures in the parentheses are t-values; ${ }^{\star}$ Significant at $5 \%$ level; ${ }^{* \star}$ Significant at $1 \%$ level

\section{Resource use efficiency}

To test the resource use efficiency, the ratio of marginal value product (MVP) to marginal factor cost (MFC) for every input was compared and tested for its equality to 1 i.e. MVP/MFC $=1$. MVP was found through multiplying the estimated co-efficient $\left(b_{i}\right)$ in the production model with the average value of product (AVP) at the geometric mean level.

According to Cobb-Douglas production function model, marginal factor cost (MFC) of all input is expressed in terms of an additional taka spent for providing individual inputs. So, in calculating the ratio of MVP to MFC the denominator would be one and therefore, the ratio would be equal to their MVP. Table 7 illustrated the MVP and the ratio of MVP to MFC and it is showed that none of the marginal value of products of inputs was equal to one. This indicates that the sample farmers in the study area had failed to show their efficiency in using the resources for both noncredit and credit borrowers.

Table 7. Resources use efficiency in Cobb-Douglas production for both non credit user and credit user in Boro rice cultivation

\begin{tabular}{lrrrrrrrrr}
\hline \multirow{2}{*}{ Explanatory variable } & \multicolumn{3}{c}{ Non credit user } & \multicolumn{2}{c}{ Grameen Bank } & \multicolumn{3}{c}{ RKUB } \\
\cline { 2 - 9 } & $\begin{array}{c}\text { Co- } \\
\text { efficient }\end{array}$ & MVP & $\begin{array}{r}\text { MVP/ } \\
\text { MFC }\end{array}$ & $\begin{array}{c}\text { Co- } \\
\text { efficient }\end{array}$ & MVP & $\begin{array}{r}\text { MVP/ } \\
\text { MFC }\end{array}$ & $\begin{array}{r}\text { Co- } \\
\text { efficient }\end{array}$ & MVP & $\begin{array}{r}\text { MVP/ } \\
\text { MFC }\end{array}$ \\
\hline \hline Seed/seedling cost $\left(X_{1}\right)$ & -0.256 & -15.73 & -15.73 & 0.594 & 29.58 & 29.58 & 0.175 & 8.93 & 8.93 \\
Fertilizer cost $\left(\mathrm{X}_{2}\right)$ & 0.155 & 2.25 & 2.25 & 0.257 & 3.01 & 3.01 & 0.122 & 1.76 & 1.76 \\
Manure cost $\left(X_{3}\right)$ & 0.176 & 3.95 & 3.95 & 0.045 & 9.16 & 9.16 & 0.113 & 2.41 & 2.41 \\
Pesticide cost $\left(X_{4}\right)$ & 0.083 & 6.62 & 6.62 & 0.0167 & 1.02 & 1.02 & 0.268 & 17.99 & 17.99 \\
Irrigation cost $\left(X_{5}\right)$ & 0.0087 & 0.078 & 0.078 & -0.0160 & -0.143 & -0.143 & 0.098 & 0.77 & 0.77 \\
Animal power/power & 0.788 & 12.07 & 12.07 & 0.0412 & 0.73 & 0.73 & -0.0107 & -0.083 & -0.083 \\
tiller cost $\left(X_{6}\right)$ & 0.663 & 2.61 & 2.61 & 0.353 & 1.39 & 1.39 & 0.267 & 0.97 & 0.97 \\
Human labor cost $\left(X_{7}\right)$ & 0.67 &
\end{tabular}

Note: MVP = Marginal value product, MFC = Marginal Factor cost, MFC $=1$ for each inputs

In case of non-borrowers farmers, the ratio of MVP to MFC for human labour, tillage, manure, fertilizer and pesticides costs were greater than one and positive. It reveals that the non-borrowers farmers had not availed themselves of the opportunity of fuller use. So there were ample opportunities for the farmers to increase production by using more of these inputs. The ratio was positive but less than one in case of irrigation cost while it was negative in case of seed or seedling cost. It implies that excessive use of these inputs had gone beyond the economic optima. Among the borrowers, the ratio of MVP to MFC for seed or seedling cost, manure, fertilizer, pesticides, and human labour costs were greater than one and positive for both GB and RKUB borrowers except human labour cost of RKUB borrowers which was less than one. It indicated that all borrowers had 
not availed themselves of the opportunity of fuller use and there were ample opportunities to increase gross return by using more of these inputs. The ratio was positive but less than one for tillage cost of GB borrowers and irrigation and human labour cost of RKUB borrowers. In that case it implies the excessive use of these resources had gone beyond economic optima. However the negative ratios were found in case of irrigation and tillage cost of GB and RKUB borrowers, respectively. This indicates the extreme uses of these inputs which in turns lead to reduction of gross return.

\section{Constraints}

Table 8 showed that there were some constraints for getting credit of sample farmers. The most important constraint was the non-availability of credit in respect of RKUB farmers. About $38 \%$ sample farmers reported that they did not get credit in time and sometimes they had to pay illegal fees. But it was not found in the case of GB farmers. So many formalities for getting loan were another important problem as mentioned by $22 \%$ and $6 \%$ of RKUB and GB farmers, respectively. In respect of GB farmers, the most important constraint was found in repaying loan by weekly instalment system and about $53 \%$ farmers expressed this problem. The overall views of the table that the small farmers usually tried to avoid such cumbersome procedure for getting loan. They prefer to borrow credit from NGOs.

\section{Table 8. Constraints of getting loan from RKUB and Grameen Bank}

\begin{tabular}{|c|c|c|c|c|}
\hline \multirow{2}{*}{ Constraints } & \multicolumn{2}{|c|}{ RKUB } & \multicolumn{2}{|c|}{ GB } \\
\hline & No & $\%$ of farmers & No & $\%$ of farmers \\
\hline Too risky & 04 & 09 & 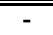 & 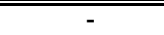 \\
\hline So many formalities & 10 & 22 & 03 & 06 \\
\hline Amount of given loan is not sufficient & 09 & 19 & - & - \\
\hline $\begin{array}{l}\text { Credit is not available in time and } \\
\text { others (Undue privilege) }\end{array}$ & 17 & 38 & - & - \\
\hline Poor farmers are neglected & 05 & 12 & - & - \\
\hline $\begin{array}{l}\text { To format group for getting credit } \\
\text { (1-5 persons) }\end{array}$ & - & - & 18 & 41 \\
\hline Weekly installment & - & - & 24 & 53 \\
\hline Total & 45 & 100 & 45 & 100 \\
\hline
\end{tabular}

\section{CONCLUSION}

The farmers of RKUB and GB used about $78 \%$ and $72 \%$ credit for Boro rice production respectively and the rest of the credit was used for consumption. GB borrowers were more benefited for MV Boro rice production than that of RKUB borrowers and non-borrowers. However, both credit users and non-users rice growers had failed to use inputs efficiently, either the production inputs were overused or underused. Unavailability of credit and weekly installment system of repaying credit were the main constraints as reported by $38 \%$ and $53 \%$ of RKUB and GB farmers, respectively.

\section{LITERATURE CITED}

BBS. 2003. Statistical Pocket Book of Bangladesh. Bangladesh Bureau of Statistics, Statistics Division, Ministry of Planning, Dhaka.

Bhaduri, A. 1973 Astudy in agricultural backwardness under semi-feudalism. Economic Journal 83(1), 1-16

GOB. 2005. Bangladesh Arthonoitic Samikha. Ministry of Finance, Finance Division, Economic Advisory Wing, Government of the People's Republic of Bangladesh.

Gujarati, D. N. 1995. Basic Econometrics. 3rd Edn, MeGra-Hill International Editions, Singapore.

Hosaain, M. 1985. Institutional credit for rural development: An overview of Bangladesh. Bangladesh J Agril Econ 8(1), 1-16.

Hossain, M. M. 1986. Credit needs of rice farmers-An analysis of farm level data. Bangladesh J Agril Econ 8(1), 1-16.

Jabber, M. A., Mondal, M. A. S. and Elahi, K. K. 1981. Usufructuary land mortgage: A process contributing to growing landless in Bangladesh. J Agril Econ 8(2), 37-52.

Jaim W. M. H and Rahman, M. L. 1985. Cash Flow of Rural Household: A Micro Level Study in Bangladesh. J Agril Econ 8(2). 